\title{
Use of alternative containers for promoting deep rooting of native forest species used for dryland restoration: the case of Acacia caven
}

\author{
Luz M De La Fuente ${ }^{(1)}$, \\ Juan F Ovalle ${ }^{(1)}$, \\ Eduardo C Arellano ${ }^{(1-2)}$ \\ Rosanna Ginocchio ${ }^{(1-2)}$
}

\begin{abstract}
The size of a container determines the development and quality of root systems. In the case of taprooted forest species used for dryland reforestation, deeper containers may favour early root development and, consequently, better soil profile colonization after outplanting. Although research on container design for worldwide tree species has been developed in the last decades, technical solutions for containerized forest species with a taproot system have been poorly documented. We present a case study using Acacia caven (Mol.) Mol., which has fast-growing taproots and long lateral and superficial roots. The aim of this study is to evaluate the effects of different containers on rooting volume in the early morphological development of $A$. caven seedlings. Ten day-old seedlings were cultivated in five different PVC container types varying in volume, width and length (T440-Short, T440-Long, T880-Short, T880-Long, and $\mathrm{T} 440-\mathrm{C})$, in a completely randomized design for one growing season. At the end of the study, whole seedling samples were destroyed to assess taproot length, lateral root biomass, and total root/shoot dry biomass. To evaluate the potential plant capacity for developing new roots, a subsequent experiment using the root growth potential test was performed successfully. Results showed that change in root volume distribution (short vs. elongated containers) had the greatest influence on seedling quality, whereas the size of container (small volume vs. large) was of minor importance. Elongated containers (35 $\mathrm{cm}$ to $40 \mathrm{~cm}$ in length) with self-pruning basal roots produced seedlings with smaller shoot/root ratios, longer root systems, and a greater ability to restart new root growth in deeper container strata. Elongated containers also prevented taproot deformation. The present study suggests that it would be appropriate to rethink container design for seedlings of deep-rooted xerophytic species destined for water-limited transplanting conditions.
\end{abstract}

Keywords: Native Tree Domestication, Root Growth Potential, Root Morphology, Seedling Quality

\section{Introduction}

Acacia trees (Leguminosae) are commonly used around the world in the restoration of degraded forest ecosystems (Dumroese et al. 2011, Jeddi \& Chaieb 2012, Hernández et al. 2015). Among these, Acacia caven is one of the most widespread Neotropical South American tree species (latitude $18^{\circ}$ to $37^{\circ} \mathrm{S}-$ Aronson 1992). It has been commonly used for the reforestation of degraded arid regions (Donoso et al. 2015), as its massive and deep-rooted system allows it to cope with a sudden abundance of water (Aronson 1992). This species generates positive interactions (facilitation) with co-occurring tree species that have lower water-stress resistance (Armesto \& Pickett 1985), as it improves both the soil nutritional level due to its high nitrogen fixation potential and the microcli- $\square$ (1) Pontificia Universidad Católica de Chile, Center of Applied Ecology \& Sustainability (CAPES), PO Box 8331150, Santiago (Chile); (2) Pontificia Universidad Católica de Chile, Departamento de Ecosistemas y Medio Ambiente, Facultad de Agronomía e Ingeniería Forestal, PO Box 7820436, Santiago (Chile)

@ Rosanna Ginocchio (rosanna.ginocchio@uc.cl)

Received: May 02, 2016 - Accepted: Jun 15, 2017

Citation: De La Fuente LM, Ovalle JF, Arellano EC, Ginocchio R (2017). Use of alternative containers for promoting deep rooting of native forest species used for dryland restoration: the case of Acacia caven. iForest 10: 776-782. - doi: 10.3832/ifor2101-010 [online 2017-0902]

Communicated by: Gianfranco Minotta matic conditions under the canopy (Aronson 1992).

Deep roots, or taproots, defined as roots that grow to depths greater than $1 \mathrm{~m}$ (Maeght et al. 2013), are functionally important for drought-adapted woody species (Schenk \& Jackson 2002a, Comas et al. 2013, Ovalle et al. 2015). Their main functions are hydraulic redistribution, resistance to embolism and to physical-chemideep soil strata, among others (Bleby et al. 2010, Johnson et al. 2014). As for early seedling survival and establishment, taproots allow rapid deep growth toward deep water sources available in soils, particularly before the first dry season ( $\mathrm{Ca}$ nadell \& Zedler 1995, Padilla \& Pugnaire 2007). Indeed, a number of studies have demonstrated a positive relationship between root length and early seedling survival in arid (León et al. 2011), semiarid (Ovalle et al. 2015), and tropical dry forest ecosystems (Markesteijn \& Poorter 2009).

From a silvicultural point of view, a main challenge for nurseries is to produce containerized seedlings that mimic the root size and architecture of naturally genercal weathering, and $C$ sequestration in 
ated seedlings. However, in most cases, containers used for nursery propagation result in seedlings with restricted root de velopment and a completely different root architecture compared to natural conditions (Tsakaldimi et al. 2009, Dumroese 8 Landis 2015). This is the case with small containers $(<400 \mathrm{~mL})$, as broadly described in the literature (Romero et al. 1986, Del Campo et al. 2010, Ritchie \& Lan dis 2010, Aghai et al. 2014, Walsh et al. 2015). Chilean nurseries commonly use small containers such as black polyethylene bags, which are quite shallow with typ ical volumes lower than $400 \mathrm{~mL}$ (Ovalle et al. 2015). In addition, black polyethylene bags absorb solar radiation and increase substrate temperatures, which retards root growth at temperatures greater than $30{ }^{\circ} \mathrm{C}$. Reduced volume in containers does not promote lateral root self-pruning at early growth stages, and this often results in root deformation, which further restricts growth (Dominguez-Lerena et al. 2006). Limitations of small containers result in serious morphological constraints and higher shoot/root ratios. This has a strong and negative impact on seedlings' water economy after they are outplanted, particularly under arid and semiarid climate conditions (Romero et al. 1986, Tsakaldimi et al. 2005). In the last decade, there has been an increasing interest in improving seedling quality of deep-rooting Mediterranean tree species, including the redesign of propagation containers (Chirino et al. 2008, Mariotti et al. 2015a, Ovalle et al. 2016). Traditional nursery cultural practices meant to improve the quality of seedlings have been developed mostly for tree species belonging to North American boreal forests ( $\mathrm{Ha}$ - ase 2005, Grossnickle 2012), which tend to develop shallow root systems (Schenk \& Jackson 2002b). By contrast, the plant quality in xeric environments is related to the development of drought-tolerant traits (Cortina et al. 2013) such as low specific leaf area, large stem diameter, low shoot/ root ratio, and large root volume (Trubat et al. 2006). These traits need to be achieved at early propagation stages. In this context, large-volume containers with better volume distribution would facilitate taproot growth and improve whole plant quality for xerophytic species, assuring proper root functionality for the seedlings' survival and establishment in soils with low water availability (Bengough et al. 2011). Several studies have reported on a positive relationship between large-volume containers, root systems (Mariotti et al. 2015a) and seedlings' total height (Akpo et al. 2014). An increase of up to $40 \%$ in root biomass has been obtained by doubling container volume (Poorter et al. 2012), and significant improvements in root growth capacity, root hydraulic conductance, and stomatal conductance have been obtained with containers above $500 \mathrm{~mL}$ in volume and $25 \mathrm{~cm}$ in depth (Chirino et al. 2008). Furthermore, spiral root prevention, generation of lateral roots, and improvements in root distribution and fibrosity have resulted from the inclusion of container walls to promote self-pruning of basal and lateral roots (Ritchie \& Landis 2010).

No documented studies provide evidence concerning the quality of plant attributes of $A$. caven seedling production, which are commonly used in the reforestation of highly degraded dry land. It is necessary to evaluate the application of nursery prac-

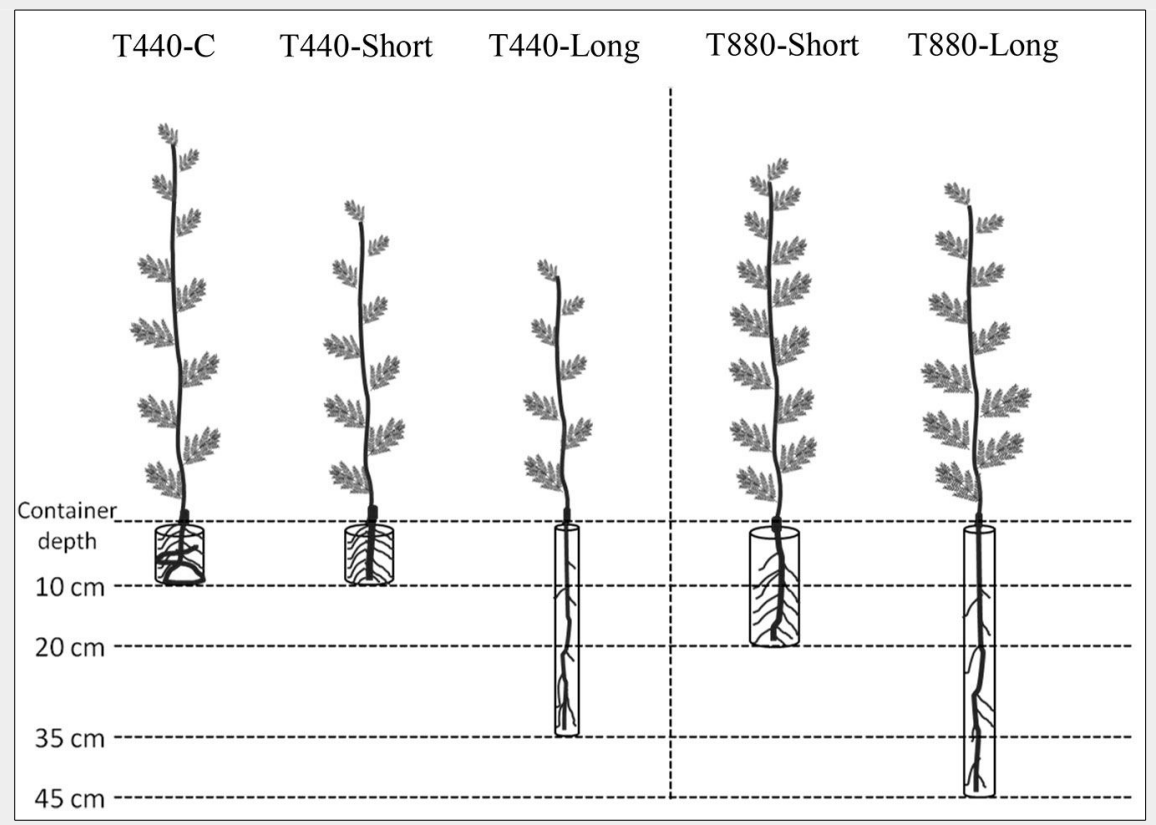

Fig. 1 - Graphical representation of container types (treatments) used for Acacia caven seedlings' growth under experimental conditions. Treatments (container volume, container length): T440-C (440 mL, $10 \mathrm{~cm})$; T440-Short $(440 \mathrm{~mL}, 10 \mathrm{~cm})$; T440-Long $(440 \mathrm{~mL}, 35 \mathrm{~cm})$; T880-Short $(880 \mathrm{~mL}, 20 \mathrm{~cm})$; T880-Long $(880 \mathrm{~mL}, 45 \mathrm{~cm})$. tices commonly used for other productive tree species (Quiroz et al. 2012) to improve nursery management of deep-rooted xerophytic species. In the present study, we evaluate the effect of container size and volume distribution on $A$. caven seedlings during early plant development.

\section{Materials and methods}

\section{Experimental conditions and plant material}

Acacia caven seedlings were cultivated in a growth room at Centro de Investigación Minera y Metalúrgica (CIMM) in Santiago, Chile $\left(33^{\circ} 26^{\prime} \mathrm{S}-74^{\circ} 40^{\prime} \mathrm{W}\right)$. Inside the controlled growth room, the established mean temperature was $23 \pm 2{ }^{\circ} \mathrm{C}$, relative humidity was $46 \%$, and light intensity was 273 umol s-1 $\mathrm{m}^{-2}$, with a $12 / 12 \mathrm{~h}$ photoperiod. Seedlings were produced from seeds collected from individual trees growing in Elqui Province, north-central Chile $\left(29^{\circ} 49^{\prime}\right.$ $\mathrm{S}-70^{\circ} 48^{\prime} \mathrm{W}$ ). The seeds were subjected to chemical scarification with concentrated sulfuric acid (technical quality) for $120 \mathrm{~min}$ utes before they were used. They were then germinated in $1-\mathrm{L}$ containers filled with A-6 perlite substrate (Harborlite ${ }^{\circledR}$ ). The average final seedling size (length) before transplantation to experimental containers was $3 \mathrm{~cm}$ for shoots, $5 \mathrm{~cm}$ for root systems, and a pair of well-developed true leaves. No root malformation at the taproot was observed. Seedlings were individually transplanted to experimental containers filled with substrate (described below Fig. 1). Water content of the containers was daily checked and when it reached $40 \%$ field capacity, demineralized water was added up to $80 \%$ field capacity. Seedlings were fertilized twice along the assay with $40 \mathrm{~mL}$ of a modified Hoagland's solution containing $150 \mathrm{mg} \mathrm{N} \mathrm{L}^{-1}, 80 \mathrm{mg} \mathrm{P} \mathrm{L}^{-1}$, and 100 $m g \mathrm{~K} \mathrm{~L}^{-1}$. Seedlings were grown for six months until control seedlings reached 60 $\mathrm{cm}$ in height, which is the average size equivalent to a plant of this species after one nursery season in central Chile.

\section{Experimental design and treatments}

The study was conducted in two stages. The first stage consisted of an experiment with five treatments distributed randomly over the benches in the plant growth room, using containers of different sizes and with varying volume distributions: T440-Short (440 mL, $10 \mathrm{~cm}$ in length, 7.5 $\mathrm{cm}$ in diameter), T440-Long (440 mL, $35 \mathrm{~cm}$ in length, $4.0 \mathrm{~cm}$ in diameter), T880-Short $(880 \mathrm{~mL}, 20 \mathrm{~cm}$ in length, $7.5 \mathrm{~cm}$ in diameter), T880-Long ( $880 \mathrm{~mL}, 45 \mathrm{~cm}$ in length, $5.0 \mathrm{~cm}$ in diameter), plus the control treatment T440-C ( $440 \mathrm{~mL}, 10 \mathrm{~cm}$ in length, 7.5 $\mathrm{cm}$ in diameter - Fig. 1). To obtain different sizes and rooting volume distributions, containers with the same volume $(440 \mathrm{~mL}$ or $880 \mathrm{~mL}$ ) but different lengths (from 10 $\mathrm{cm}$ to $45 \mathrm{~cm}$ in length) were used (Fig. 1). Experimental containers were made of PVC (polyvinyl chloride) tubes. The control 
treatment was a $12 \times 15 \mathrm{~cm}$ black polyethylene bag of $440 \mathrm{~mL}$, which is the most commonly used container in local tree nurseries (Ovalle et al. 2015). To promote selfpruning of basal roots and good drainage, all PVC containers were cut vertically in their bases ( $3 \mathrm{~cm}$ long every $3 \mathrm{~cm}$ ), and a 2 $\times 2 \mathrm{~mm}$ plastic mesh opening was glued to the base. To favour lateral self-pruning of secondary roots, side slots were made along each PVC container. PVC containers were left suspended (in contact with air) on a plastic structure. Seedling density was 82 plants per $\mathrm{m}^{2}$. The distribution of treatments in the plastic structure was randomized with 16 replications per treatment (80 seedlings in total).

The substrate used to fill the experimental containers up to $88 \%$ of their volume was a mixture of one part A-6 perlite (Harborlite ${ }^{\circledast}$ ), one-part peat (Kekkilä DSM), and two parts loam soil. To maintain constant substrate density in all treatments, the correlation between weight of the substrate and container volume was considered. The substrate volume used for the treatments T440-C, T440-Short, and T440-Long was $385 \mathrm{~mL}$, while a volume of $770 \mathrm{~mL}$ was used for the treatments T880-Short and T880-Long.

\section{Seedlings' morphological measurements}

From each treatment, six randomly chosen seedlings were assessed for morphology measurements (Trubat et al. 2010). Morphological variables measured were shoot height, root collar diameter (RCD), shoot dry biomass, root dry biomass, shoot height/RCD ratio, and shoot/root dry biomass ratio. Shoot height was measured with a graduated metal ruler from the substrate surface to the apex of the main stem. RCD was measured with a digital calliper below the insertion of the cotyledons. To determine dry biomass, plant tissues were washed with tap water and dried at $45{ }^{\circ} \mathrm{C}$ in an air-forced oven until constant weight was reached. Taproot length was measured with scanned images obtained from the root system, after being thoroughly washed with tap water. For taproot length, container depth and the presence of spiral roots were considered. Shoot height and RCD were evaluated once a month for all plants. The remaining variables were evaluated only at the end of the assay, six months after establishment.

\section{Root growth potential tests}

The second stage of the experiment was performed to assess the potential capability of roots to produce new growth after growing in different containers. Therefore, the root growth potential (RGP) test was performed following the methodology used by Ritchie (1985) and Trubat et al. (2010). Six plants per treatment were randomly selected at the end of the first stage of experimentation and transplanted into a larger PVC container (70 cm wide). PVC tubes were longitudinally cut into two parts to facilitate the final evaluation. The size of containers varied according to the initial treatment, but the plants had equal space left for further growth $(3 \mathrm{~cm}$ to each side of the original root plug and $20 \mathrm{~cm}$ to the base). The experimental substrate used to fill the containers was A- 6 perlite (Harborlite ${ }^{\circledR}$ ). The containers were irrigated twice a week with demineralized water up to $100 \%$ field capacity. RGP tests lasted for 28 days (Ritchie 1985), as assessed from a pre-test with the objective of determining the number of days required for $A$. caven roots to grow in the container without reaching the bottom. After cultivation, each container was longitudinally opened and divided into transverse $10-\mathrm{cm}$-deep sections; the number of roots larger than 1 $\mathrm{cm}$ (Chirino et al. 2008) per section was then determined. New root growth in terms of dry biomass was also analysed; new roots were cut by hand, washed, and dried at $45{ }^{\circ} \mathrm{C}$ in an air-forced oven until constant weight was reached.

\section{Data analysis}

One-way analysis of variance (ANOVA) was used to specify significant differences $(P<0.05)$ among treatments for each response variable evaluated in the first stage of the experiment. For the RGP test, oneway ANOVA was used to determine signifi- cant differences $(P<0.05)$ among treatments for each substrate depth section of the containers. Fisher's LSD test was used to discriminate between treatments ( $P$ $<0.05)$. Prior to the ANOVA, data normality was verified by the Shapiro-Wilks test and the homogeneity of variances by Levene's test. If requirements were not met, data was transformed or analysed using the nonparametric Kruskal-Wallis test. All statistical analyses were performed with InfoStat ${ }^{\circledR}$ software v. 2010.

\section{Results}

\section{Morphological parameters}

The different container types resulted in significant effects $(P<0.05)$ on $A$. caven seedlings' shoot height, RCD, shoot height/ RCD ratio, and taproot length (Tab. 1). In general, containers with higher volume (T880-Short and T880-Long) did not exhibit a clear pattern for morphological parameters when they were compared to containers with lower volume (T440-Short, T440-Long and T440-C - Fig. 1). Seedlings that were grown in 440-mL containers had significantly higher shoot height and shoot height/RCD ratio $(P<0.05)$ for the control treatment compared to the short and elongated containers. RCD was significantly higher $(P<0.05)$ for seedlings grown in short containers (T440-C, T440-Short, and T880-Short), independent of container volume. No significant differences were found between type of container for shoot biomass, root biomass, shoot/root dry biomass ratio, or Dickson quality index (DQI Tab. 1). Treatment with the largest container (T880-Long) promoted significantly longer taproot length $(P<0.05)$ in relation to the other treatments and control. By contrast, short containers (T440-C, T440Short, and T880-Short) showed small taproot growth (Tab. 1) and root deformation at the container base. Therefore, container depth influenced taproot length. In addition, the taproot in T440-C was three times longer than that in T440-Short. In T440-C, $67 \%$ of the seedlings had spiral roots, while those grown in containers with side holes (T440-Short, T440-Long, T880-Short, and

Tab. 1 - Morphological parameters of Acacia caven seedlings after six months growing in experimental containers. Mean \pm standard error values are given. Different letters indicate significant differences among treatments according to one-way ANOVA and Fisher's LSD tests $(P<0.05)$. Treatments (container volume, container length): T440-C $(440 \mathrm{~mL}, 10 \mathrm{~cm}) ;$ T440-Short $(440 \mathrm{~mL}, 10 \mathrm{~cm}) ; \mathrm{T} 440-$ Long (440 mL, $35 \mathrm{~cm})$; T880-Short $(880 \mathrm{~mL}, 20 \mathrm{~cm})$; T880-Long $(880 \mathrm{~mL}, 45 \mathrm{~cm})$.

\begin{tabular}{|c|c|c|c|c|c|c|c|}
\hline \multirow{2}{*}{$\begin{array}{l}\text { Morphological } \\
\text { parameter }\end{array}$} & \multicolumn{5}{|c|}{ Treatments } & \multirow{2}{*}{$F$-value } & \multirow{2}{*}{$P$-value } \\
\hline & T440-C & T440-Short & T440-Long & T880-Short & T880-Long & & \\
\hline Shoot height $(\mathrm{cm})$ & $63.4 \pm 3.7^{\mathrm{a}}$ & $50.0 \pm 3.8^{\mathrm{bc}}$ & $41.0 \pm 2.6^{c}$ & $55.5 \pm 4.4^{\mathrm{ab}}$ & $52.7 \pm 3.4^{\mathrm{b}}$ & 5.13 & $<0.05$ \\
\hline $\mathrm{RCD}(\mathrm{mm})$ & $4.0 \pm 0.1^{\mathrm{a}}$ & $3.9 \pm 0.2^{\mathrm{a}}$ & $3.3 \pm 0.1^{b}$ & $4.0 \pm 0.1^{a}$ & $3.6 \pm 0.1^{b}$ & 7.10 & $<0.05$ \\
\hline Shoot height/RCD ratio & $157.6 \pm 8.1^{\mathrm{a}}$ & $126.2 \pm 7.4^{\mathrm{b}}$ & $125.7 \pm 6.8^{\mathrm{b}}$ & $139.6 \pm 8.9^{a b}$ & $147.9 \pm 8.2^{\mathrm{ab}}$ & 3.06 & $<0.05$ \\
\hline Shoot biomass (g) & $1.6 \pm 0.3$ & $1.5 \pm 0.2$ & $0.8 \pm 0.1$ & $1.9 \pm 0.4$ & $1.6 \pm 0.2$ & 2.44 & 0.073 \\
\hline Root biomass (g) & $1.1 \pm 0.1$ & $1.2 \pm 0.3$ & $0.7 \pm 0.1$ & $1.4 \pm 0.2$ & $1.3 \pm 0.2$ & 1.80 & 0.161 \\
\hline Shoot/root ratio & $1.4 \pm 0.2$ & $1.3 \pm 0.2$ & $1.1 \pm 0.1$ & $1.4 \pm 0.1$ & $1.2 \pm 0.1$ & 1.01 & 0.422 \\
\hline Taproot length (cm) & $18.8 \pm 3.5^{\mathrm{b}}$ & $6.9 \pm 0.3^{c}$ & $26.1 \pm 0.9^{\mathrm{ab}}$ & $12.6 \pm 0.5^{\mathrm{bc}}$ & $33.7 \pm 0.5^{\mathrm{a}}$ & 24.20 & $<0.05$ \\
\hline Dickson Quality Index (DQI) & $0.18 \pm 0.02$ & $0.19 \pm 0.04$ & $0.12 \pm 0.01$ & $0.20 \pm 0.03$ & $0.18 \pm 0.02$ & 1.50 & 0.231 \\
\hline
\end{tabular}


Tab. 2 - Root morphology characteristics of Acacia caven seedlings after the root growth potential (RGP) tests. Mean \pm standard error values are given. Different letters indicate significant differences among treatments according to one-way ANOVA and Fisher's LSD tests $(P<0.05)$. Treatments: T440-C (440 mL, $10 \mathrm{~cm}$ in length); T440-Short ( $440 \mathrm{~mL}, 10 \mathrm{~cm}$ in length); T440-Long ( $440 \mathrm{~mL}, 35 \mathrm{~cm}$ in length); T880-Short ( $880 \mathrm{~mL}, 20 \mathrm{~cm}$ in length); T880-Long ( $880 \mathrm{~mL}, 45 \mathrm{~cm}$ in length).

\begin{tabular}{|c|c|c|c|c|c|c|c|}
\hline \multirow{2}{*}{ Parameter } & \multicolumn{5}{|c|}{ Treatments } & \multirow{2}{*}{$F$-value } & \multirow{2}{*}{$P$-value } \\
\hline & T440-C & T440-Short & T440-Long & T880-Short & T880-Long & & \\
\hline Root biomass (mg) & $115.9 \pm 29.7$ & $87.8 \pm 11.8$ & $77.0 \pm 12.2$ & $109.9 \pm 28.1$ & $147.1 \pm 31.3$ & 1.26 & 0.311 \\
\hline Root number & $71 \pm 15$ & $71 \pm 5$ & $60 \pm 9$ & $94 \pm 16$ & $111 \pm 29$ & 1.50 & 0.233 \\
\hline Root length $(\mathrm{cm})$ & $22.3 \pm 3.9$ & $25.6 \pm 1.7$ & $23.2 \pm 2.0$ & $21.2 \pm 3.8$ & $24.3 \pm 1.4$ & 0.38 & 0.824 \\
\hline Root length/Container length (\%) & $223 \pm 40^{c}$ & $256 \pm 17^{c}$ & $66 \pm 6^{\mathrm{ab}}$ & $106 \pm 19^{b}$ & $54 \pm 3^{a}$ & 16.06 & $<0.05$ \\
\hline
\end{tabular}

T880-Long) did not have spiral roots (Tab. 1).

\section{Root growth potential test}

No significant differences concerning root biomass or total number of new roots were found among treatments for $A$. caven seedlings after the RGP test (Tab. 2). However, significant effects $(P<0.05)$ were found in terms of root length/container length (\%), as expected. Seedlings of the T880-Long treatment tended to produce greater root biomass than the other treatments, including the control. By contrast, the T440-Long treatment tended to produce the lowest root biomass. Comparing short containers of different sizes, we observed that root biomass of T880-Short was $25 \%$ larger than that of the T440-Short treatment, because the former has twice the volume. A similar tendency was detected for elongated containers where T880-Long produced twice the biomass of the T440-Long treatment. In terms of the number of new roots, larger containers (T880-Short and T880-Long) tended to produce larger amounts compared to small containers and the control.

Although there were no significant differences in root biomass and number of new roots, the distribution of these parameters varied with container depth (Fig. 2). Biomass and new roots were mainly concentrated at the location of the base of the first-stage root plug, except for T440-Short and T440-Long, in which the biomass and new roots were concentrated under the dotted line (Fig. 2). In Fig. 2, the point where the biomass curve intercepts the root number curve corresponds to $0.75 \mathrm{mg}$ of biomass per root. When the root biomass curve is located to the left of the root number curve, the roots have a value less than $0.75 \mathrm{mg}$, which we define as "thin roots". On the other hand, when the biomass curve is located to the right of the root number curve, the roots have a value greater than $0.75 \mathrm{mg}$, which we define as "thick roots". Furthermore, it was observed that thick roots were concentrated under the dotted line and thin roots dominated above the dotted line (Fig. 2). In general, diverse criteria are used to define root size in plant studies. Generally, root diameter is the most common parameter to define size root classification. In some studies, thin or fine roots are defined as those less than $2 \mathrm{~mm}$, while thick or coarse roots are defined as those greater than $2 \mathrm{~mm}$ (Ghestem et al. 2014, Ovalle et al. 2015) or $4.5 \mathrm{~mm}$ (Peman et al. 2006) in diameter.

Seedling roots of T440-C and T440-Short treatments colonized and were concentrated up to $30 \mathrm{~cm}$ in depth, while seedling roots of T880-Short and T880-Long treatments colonized up to $40 \mathrm{~cm}$ and $70 \mathrm{~cm}$ in depth, respectively. Seedling roots of T440-Long, which had half the volume of
T880-Short and T880-Long, colonized up to $60 \mathrm{~cm}$ in depth (Fig. 2).

\section{Discussion}

The present study confirms that container characteristics have important implications on seedling morphology of deeprooting species such as $A$. caven. Among the morphological variables influenced by type of container, a change in rooting volume distribution (short versus elongated container) was the most important, whereas container size (small versus large volume) had a minor influence on taproot length and RCD. Different plant responses to container type have been described by other authors for Mediterranean tree species (Chirino et al. 2008, Mariotti et al. 2015a), and in many cases the differences depend on root growth strategies (Schuch et al. 2000).

Field and experimental evidence has shown that direct sowing of tree species with a taproot system produces trees that can cope with water restrictions more effectively than those grown in nurseries and outplanted in field conditions, because of greater development of taproots (Zadworny et al. 2014). Therefore, elongated containers guarantee higher rates of seedling survival under semiarid conditions (Vallejo et al. 2012) as the root development mimics seedling growth under natural conditions. According to Peman et al. (2006), water

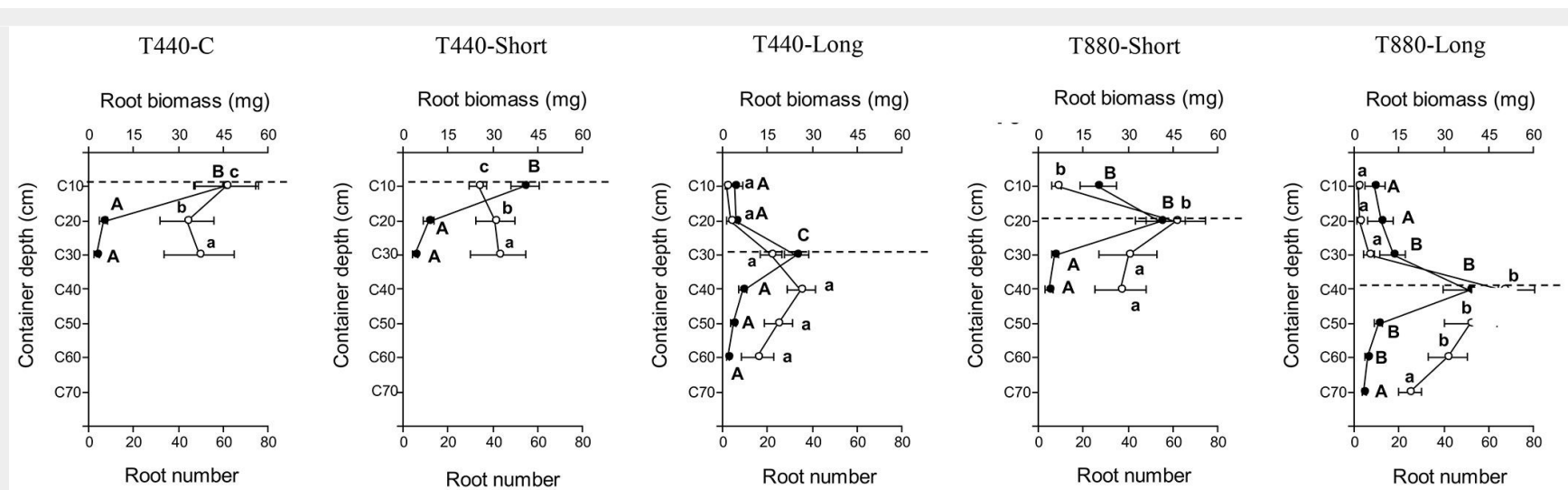

Fig. 2 - Distribution of new root biomass (white circles and lowercase letters) and new roots number (filled circles and capital let ters) of Acacia caven seedlings for the root growth potential (RGP) test. Different letters indicate significant differences among treatments for each section of the container. The dotted line indicates the depth where the base of the first stage assay root plug was located. 
uptake efficiency could be seriously diminished by the confinement effect that plant roots suffer in short containers $(20 \mathrm{~cm}$ in length). In addition, the same authors suggest that restrictions to vertical root growth of Quercus ilex result in total lower root lengths. In our study, we observed that elongated containers ( 35 to $45 \mathrm{~cm}$ in length), independent of their volume, promoted larger increases in taproot length than shorter containers. In fact, the largest container type (T880-Long) quintupled the length achieved in the smallest container (T440-Short). Similar results were found by Chirino et al. (2008) using 30-cm-deep containers, where taproots reached $30 \mathrm{~cm}$ in length. In the same study, the 30-cm-deep containers were also associated with higher shoot and root biomass compared to the $18-\mathrm{cm}$ container type.

In relation to the other plant quality attributes, the shoot height/RCD ratio values of all experimental treatments were greater than 100, indicating that the plants were very tall with regard to their $R C D$ (Quiroz et al. 2009). Therefore, this type of plant may be considered too slender or insufficiently robust for semiarid environments (Navarro et al. 2006). This response may be explained by the low level of photosynthetic active radiation (PAR) available in the plant growth room used for the present study, compared to the effects produced in plants cultivated under higher PAR found in Mediterranean areas (Tattini et al. 2006). However, shorter containers promoted larger increases in RCD (increases of approximately $4 \mathrm{~mm}$ ). Despite the short growing period of this study, the diameters obtained in our study meet the recommended value range for Mediterranean species seedlings (Navarro et al. 2006).

Taproots were effectively pruned in all containers (T440-Short, T440-Long, T880Short, and T880-Long) with basal pruning when they came into contact with air. Similar responses were reported by Mariotti et al. (2015b) using air-pots, where inhibited growth of Quercus ilex seedlings was obtained in deep pots. On the other hand, most $A$. caven seedlings grown in polyethylene bags ( $\mathrm{T} 440-\mathrm{C})$ showed spiral taproots at the base of the bag. When a plant develops a spiral root, it does not normally restart growth at depth after outplanting. Anchoring problems may occur (Dominguez-Lerena et al. 2006), and seedlings may even die (Quiroz et al. 2009). It should also be noted that deformation of the root system can persist in the soil for years after outplanting (Lindström \& Rune 1999).

In all treatments of the second stage of the experiment (RGP test), seedlings of $A$. caven were able to form new roots, indicating their potential capacity to develop roots out of the root plug once they are transplanted. Tsakaldimi et al. (2005) observed for two Mediterranean evergreen oak species that seedlings restricting their roots to the root plug space do not survive once they are transplanted into soil. The RGP test showed that thinner roots developed on the sides of the root plug, which are potentially better surfaces for water absorption and nutrient uptake (Dominguez-Lerena et al. 2006). Thicker root growth restarted at the base of the root plug, which improves anchorage and allows water absorption from deep soil layers. For example, in Q. suber plants. the largest concentration of biomass is located between 40 and $60 \mathrm{~cm}$ in depth (Chirino et al. 2008), similar to the results of the RGP test with $A$. caven seedlings grown in elongated containers (T440-Long). The soil at $60 \mathrm{~cm}$ depth is significantly wetter than at $30 \mathrm{~cm}$ depth, which favours the survival of early growth stages under field conditions.

A minimum volume of $300 \mathrm{~mL}$ for propagation containers has been recommended for dry climates (Dominguez-Lerena et al. 2006, Puértolas et al. 2012). However, Del Campo et al. (2010) found a negative effect on seedling quality in containers ranging from 250 to $300 \mathrm{~mL}$, which resulted in an early halt to plant growth due to increased tissue lignification. On the other hand, larger containers $(>300 \mathrm{~mL}$ ) increase production costs as they require more substrate and occupy larger surfaces at the nursery (Mariotti et al. 2015a). Larger containers also result in higher planting costs associated with increased soil movement (Puértolas et al. 2012), among others. Under these considerations and according to our findings, 440-mL containers are the most appropriate for the cultivation of $A$. caven seedlings. Specifically, the T440Long container type has the greatest advantage as it has a smaller diameter and thus uses less space in the nursery.

Enhanced development of taproots without deformation at the container base is a key aspect before outplanting, as it assures resistance to severe and long drought periods in semiarid Mediterranean ecosystems. Therefore, our results suggest that adequate root development at early growth stages of seedlings would improve waterstress resistance under semiarid conditions, as also stated by Peman et al. (2006). However, this needs to be evaluated under real field conditions. Some studies that evaluated post-transplant effects on seedlings grown in large-volume containers reported that those with greater availability of space for root growth resulted in larger height and diameter, better nutritional status, and higher survival rates (DominguezLerena et al. 2006). Therefore, the present study stresses the relevance of improving characteristics of propagation containers for xerophytic deep-rooting species destined for semiarid environments.

\section{Conclusions}

The rooting volume distribution of propagation containers positively affects taproot development of $A$. caven seedlings. Specifically, elongated containers $(35 \mathrm{~cm}$ to $40 \mathrm{~cm}$ in length) with basal root self-pruning, such as T440-Long and T880-Long, produced seedlings with smaller shoot/root ratios, longer taproots, and greater ability to restart new root growth at deeper container layers. These results could be relevant for reconsidering container designs used at the nursery phase and thus expand alternatives for growers of xerophytic tree species with taproot systems.

\section{Acknowledgements}

The authors would like to thank the Chilean Research Center for Mining and Metallurgy (CIMM) and the CONICYT FB 0002 (2014) for funding the study; Professors Eduardo Olate and Paulina Fernández for their contribution to the present study; Elisabeth Trangolao, Elena Bustamante, Margaret Opazo and Marcela Jimenez for their help with the experiments; and Consuelo Gazitúa for helping with graphical presentations.

\section{References}

Aghai MM, Pinto JR, Davis AS (2014). Container volume and growing density influence western larch (Larix occidentalis Nutt.) seedling development during nursery culture and establishment. New Forests 45: 199-213. - doi: 10.1007/ s11056-013-9402-8

Akpo E, Stomph TJ, Kossou DK, Omoreb A, Struik P (2014). Effects of nursery management practices on morphological quality attributes of tree seedlings at planting: the case of oil palm (Elaeis guineensis Jacq.). Forest Ecology and Management 324: 28-36. - doi: 10.1016/j.foreco. 2014.03.045

Armesto JJ, Pickett S (1985). A mechanistic approach to the study of succession in the Chilean matorral. Revista Chilena de Historia Natural 58: 9-17.

Aronson J (1992). Evolutionary biology of Acacia caven (Leguminosae, Mimosoideae): infraspecific variation in fruit and seed characters. Annual Report of the Missouri Botanical Garden 79: 958-968. - doi: 10.2307/2399726

Bengough G, McKenzie BM, Hallett PD, Valentine T (2011). Root elongation, water stress, and mechanical impedance: a review of limiting stresses and beneficial root tip traits. Journal of Experimental Botany 62: 59-68. - doi: 10.1093/ jxb/erq350

Bleby TM, McElrone AJ, Jackson RB (2010). Water uptake and hydraulic redistribution across large woody root systems to $20 \mathrm{~m}$ depth. Plant Cell and Environment 33: 2132-48. - doi: 10.1111/ j.1365-3040.2010.02212.x

Canadell J, Zedler P (1995). Underground structures of woody plants in Mediterranean ecosystems of Australia, California, and Chile. In: "Ecology and biogeography of Mediterranean ecosystems in Chile, California, and Australia" (Arroyo M, Zedler P, Fox M eds). Springer, Berlin Heidelberg New York, pp. 177-210. - doi: 10.1007/978-1-4612-2490-7_8

Chirino E, Vilagrosa A, Hernández E, Matos A, Vallejo R (2008). Effects of a deep container on morpho-functional characteristics and root colonization in Quercus suber L. seedlings for reforestation in Mediterranean climate. Forest Ecology and Management 256: 779-785. - doi: 
10.1016/j.foreco.2008.05.035

Comas LH, Becker SR, Cruz VM, Byrne P, Dierig D (2013). Root traits contributing to plant produc tivity under drought. Frontiers Plant Science 4: 1-16. - doi: 10.3389/fpls.2013.00442

Cortina J, Vilagrosa A, Trubat R (2013). The role of nutrients for improving seedling quality in drylands. New Forests 44: 719-732. - doi: 10.1007 /s11056-013-9379-3

Del Campo A, Navarro R, Ceacero C (2010). Seedling quality and field performance of commercial stocklots of containerized holm oak (Quercus ilex) in Mediterranean Spain: an approach for establishing a quality standard. New Forests 39: 719-732. - doi: 10.1007/s11056-009-9152-9 Dominguez-Lerena S, Herrero N, Carrasco I, Ocaña L, Peñuelas JL, Mexal JG (2006). Container characteristics influence Pinus pinea seedling development in the nursery and field. Forest Ecology and Management 221: 63-71. - doi: 10.1016/j.foreco.2005.08.031

Donoso S, Peña-Rojas K, Pacheco C, Durán S, Santelices R, Mascaró C (2015). The physiological and growth response of Acacia caven under water stress and the application of different levels of biosolids. Ciencia e Investigación Agraria 42: 273-283. - doi: 10.4067/S0718-1620201500 02000013

Dumroese RK, Davis AS, Jacobs DF (2011). Nursery response of Acacia koa seedlings to container size, irrigation method, and fertilization rate. Journal of Plant Nutrition 34: 877-887. doi: 10.1080/01904167.2011.544356

Dumroese RK, Landis TD (2015). Growing container seedlings: three considerations. Tree Planter's Notes 58: 58-62. [online] URL: http:// www.fs.fed.us/rm/pubs_journals/2015/rmrs_201 5 dumroese k004.pdf

Ghestem M, Veylon G, Bernard A, Vanel Q, Stokes A (2014). Influence of plant root system morphology and architectural traits on soil shear resistance. Plant and Soil 377: 43-61. - doi: 10.1007/s11104-012-1572-1

Grossnickle SC (2012). Why seedlings survive: influence of plant attributes. New Forests 43: 711-738. - doi: 10.1007/s11056-012-9336-6

Haase DL (2005). Understanding forest seedling quality: measurements and interpretation. Tree Planter's Notes 52: 24-30.

Hernández A, Miranda M, Arellano EC, Saura S, Ovalle C (2015). Landscape dynamics and their effect on the functional connectivity of a Mediterranean landscape in Chile. Ecological Indicators 48: 198-206. - doi: 10.1016/j.ecolind.2014. 08.010

Jeddi K, Chaieb M (2012). Restoring degraded arid Mediterranean areas with exotic tree species: Influence of an age sequence of Acacia salicina on soil and vegetation dynamics. Flora Morphology, Distribution, Functional Ecology Plants 207: 693-700. - doi: 10.1016/j.flora.2012. 07.002

Johnson DM, Brodersen CR, Reed M, Domec JC, Jackson R (2014). Contrasting hydraulic architecture and function in deep and shallow roots of tree species from a semi-arid habitat. Annals of Botany 113: 617-27. - doi: 10.1093/aob/mct294 León MF, Squeo F, Gutiérrez JR, Holmgren M (2011). Rapid root extension during water pulses enhances establishment of shrub seedlings in the Atacama desert. Journal of Vegeta- tion Science 22: 120-129. - doi: 10.1111/j.16541103.2010.01224.x

Lindström A, Rune G (1999). Root deformation in plantations of container-grown Scots pine trees: effects on root growth, tree stability and stem straightness. Plant and Soil 217: 29-37. doi: 10.1023/A:1004662127182

Maeght J-L, Rewald B, Pierret A (2013). How to study deep roots and why it matters. Frontiers in Plant Science 4: 1-14. - doi: 10.3389/fpls.20 13.00299

Mariotti B, Maltoni A, Chiarabaglio PM, Giorcelli A, Jacobs DF, Tognetti R, Tani A (2015a). Can the use of large, alternative nursery containers aid in field establishment of Juglans regia and Quercus robur seedlings? New Forests 46: 773794. - doi: 10.1007/s11056-015-9505-5

Mariotti B, Maltoni A, Jacobs DF, Tani A (2015b). Container effects on growth and biomass allocation in Quercus robur and Juglans regia seedlings. Scandinavian Journal of Forest Research 30: 401-415. - doi: 10.1080/02827581. 2015.1023352

Markesteijn L, Poorter L (2009). Seedling root morphology and biomass allocation of 62 tropical tree species in relation to drought- and shade-tolerance. Journal of Ecology 97: 311-325. doi: 10.1111/j.1365-2745.2008.01466.x

Navarro R, Villar-Salvador P, Campo A (2006). Morfología y establecimiento de los plantones [Morphology and seedling establishment]. In: "Calidad de planta forestal para la restauración en ambientes Mediterráneos" [Tree plant quality for restoring Mediterranean ecosystem] (Cortina J, Puértolas J, Savé R, Vilagrosa A eds). Serie forestal, Ministerio de Medio Ambiente, Madrid, Spain, pp. 67-88. [in Spanish]

Ovalle JF, Arellano EC, Ginocchio R (2015). Tradeoffs between drought survival and rooting strategy of two South American Mediterranean tree species: implications for dryland forests restoration. Forests 6: 3733-3747. - doi: 10.3390/ f6103733

Ovalle JF, Arellano EC, Ginocchio R, Becerra P (2016). Fertilizer location modifies root zone salinity, root morphology, and water stress resistance of tree seedlings according to the watering regime in a dryland reforestation. Journal of Plant Nutrition and Soil Science 179: 223-233. - doi: 10.1002/jpln.201500181

Padilla FM, Pugnaire FI (2007). Rooting depth and soil moisture control Mediterranean woody seedling survival during drought. Functional Ecology 21: 489-495. - doi: 10.1111/j.13652435.2007.01267.x

Peman J, Gil-Pelegrin E, Voltas J (2006). Morphological and functional variability in the root system of Quercus ilex L. subject to confinement: consequences for afforestation. Annals of Forest Science 63: 425-430. - doi: 10.1051/forest: 2006022

Poorter H, Bühler J, Van Dusschoten D, Climent J, Postma J (2012). Pot size matters: a metaanalysis of the effects of rooting volume on plant growth. Functional Plant Biology 39: 839850. - doi: 10.1071/FP12049

Puértolas J, Jacobs DF, Benito LF, Peñuelas JL (2012). Cost-benefit analysis of different container capacities and fertilization regimes in Pinus stock-type production for forest restoration in dry Mediterranean areas. Ecological
Engineering 44: 210-215. - doi: 10.1016/j.ecoleng. 2012.04.005

Quiroz I, García E, González M, Chung P, Soto H (2009). Producción de plantas a raíz cubierta [Container stocktypes production]. In: "Vivero Forestal: Producción de plantas nativas a raíz cubierta [Forest Nursery: Container Stocktypes Production of Native Tree Species]" (Quiroz I ed). INFOR Sede Bío-Bío, Concepción, Chile, pp. 128. [in Spanish]

Quiroz I, Gutiérrez B, García E (2012). Bases para un reglamento de semillas y plantas de especies forestales utilizadas en Chile [Rules for seeds and plants production of native tree species used in Chile]. INFOR Sede Bío-Bío, Concepción, Chile. pp. 76. [in Spanish]

Ritchie G, Landis T (2010). The container tree nursery manual. Agriculture Handbook, USDA Forest Service, Washington, DC, USA, pp. 674. Ritchie GA (1985). Root growth potential: principles, procedures and predictive ability. In: "Evaluating Seedling Quality: principles, procedures, and predictive abilities of major tests" (Duryea M ed). Oregon State University, Corvallis, OR, USA, pp. 93-106.

Romero A, Fisher JJT, Mexal JG (1986). Root sys tem modification of container stock for arid land plantings. Forest Ecology and Management 16: 281-290. - doi: 10.1016/0378-1127(86)90 028-9

Schenk J, Jackson R (2002a). Rooting depths, lateral root spreads and below-ground/aboveground allometries of plants in water-limited. Journal of Ecology 90: 480-494. - doi: 10.1111/ j.1469-8137.2006.01723.x

Schenk J, Jackson RB (2002b). The global biogeography of roots. Ecological Monographs 72: 311-328. - doi: 10.1890/0012-9615(2002)072

Schuch UK, Pittenger DR, Barker PA (2000). Comparing effects of container treatments on nursery production and field establishment of trees with different root systems. Journal of Environmental Horticulture 18: 83-88. [online] URL: http://www.hrijournal.org/doi/abs/10.242 66/0738-2898-18.2.83?code=hrin-site

Tattini M, Remorini D, Pinelli P, Agati G, Saracini E, Traversi ML, Massai R (2006). Morphoanatomical, physiological and biochemical adjustments in response to root zone salinity stress and high solar radiation in two Mediterranean evergreen shrubs, Myrtus communis and Pistacia lentiscus. New Phytologist 170: 779794. - doi: 10.1111/j.1469-8137.2006.01723.x

Trubat R, Cortina J, Vilagrosa A (2006). Plant morphology and root hydraulics are altered by nutrient deficiency in Pistacia lentiscus (L.). Trees - Structure and Function 20: 334-339. doi: 10.1007/s00468-005-0045-z

Trubat R, Cortina J, Vilagrosa A (2010). Nursery fertilization affects seedling traits but not field performance in Quercus suber L. Journal of Arid Environments 74: 491-497. - doi: 10.1016/j.jarid env.2009.10.007

Tsakaldimi M, Zagas T, Tsitsoni T, Ganatsas P (2005). Root morphology, stem growth and field performance of seedlings of two Mediterranean evergreen oak species raised in different container types. Plant and Soil 278: 85-93. doi: 10.1007/s11104-005-2580-1

Tsakaldimi M, Tsitsoni T, Ganatsas P, Zagas T (2009). A comparison of root architecture and 
shoot morphology between naturally regenerated and container-grown seedlings of Quercus ilex. Plant and Soil 324: 103-113. - doi: 10.1007/ s11104-009-9974-4

Vallejo R, Smanis A, Chirino E, Fuentes D, Valdecantos A, Vilagrosa A (2012). Perspectives in dryland restoration: approaches for climate change adaptation. New Forests 43: 561-579. doi: 10.1007/s11056-012-9325-9

Walsh D, Rossi S, Lord D (2015). Size and age: intrinsic confounding factors affecting the responses to a water deficit in black spruce seedlings. iForest - Biogeosciences and Forestry 8: 401-409. - doi: 10.3832/ifor1412-007
Zadworny M, Jagodzinski AM, Lakomy P, Ufnalski K, Oleksyn J (2014). The silent shareholder in deterioration of oak growth: common planting practices affect the long-term response of oaks to periodic drought. Forest Ecology and Management 318: 133-141. - doi: 10.1016/j.foreco. 2014.01.017 